V. Danyliuk ${ }^{1}$, Cand. Sc. (Econ.), orcid.org/0000-0001-7788-9029, I. Riepina ${ }^{1}$, Dr. Sc. (Econ.), Prof., orcid.org/0000-0001-9141-0117, O. Shafalyuk ${ }^{1}$, Dr. Sc. (Econ.), Prof., orcid.org/0000-0003-1145-7973,

M. Kovylina², Cand. Sc. (Econ.), Assoc. Prof., orcid.org/0000-0003-2805-9648,

V. Nitsenko ${ }^{3}$, Dr. Sc. (Econ.), Prof., orcid.org/0000-0002-2185-0341
1 - Kyiv National Economic University named after Vadym Getman, Kyiv, Ukraine

2 - National University "Odesa National Maritime Academy", Odesa, Ukraine

3 - Interregional Academy of Personnel Management, Higher Education Institution, Private Joint-Stock Company, Kyiv, Ukraine, e-mail: vitaliinitsenko@gmail.com

\title{
FUNCTIONAL AND INVESTMENT STRATEGIES OF TECHNICAL DEVELOPMENT OF ENTERPRISES
}

Purpose. To identify the links between the main elements of the strategic set of the company, to determine the problems and the possibilities of their effective implementation by cooperating business units.

Methodology. In the research on elements and subsystems, approaches and concepts of strategic enterprise management, as well as the possibilities of their effective integration, methods of system analysis were used, which ensured the effectiveness of generalizations and constructive conclusions.

Findings. The study analyzes widespread problems of imbalance between the overall strategy of enterprise development and its investment, production and functional strategies, which leads to a decrease in management effectiveness and business efficiency. The article critically analyzes different views on the concept of technical development strategy and its relationship with investment, production and functional strategies, which are usually included in the strategic set of the company; the possibilities of their complex optimization in achieving the goals of the overall development strategy are also identified.

Originality. As a result of generalizing data on the enterprise strategy system, critical points of their intersection were studied, as well as features of effective strategic management were identified.

Practical value. Based on the systematization and development of theoretical foundations, as well as the analysis of the effectiveness of strategic management of Ukrainian enterprises, for them there have been ways identified to neutralize the problems in the formation and implementation of functionally interconnected innovation-oriented strategies, improving the efficiency of investments, which are harmonized across different strategic horizons.

Keywords: investments, innovation, technical development, strategy, management

Introduction. According to the author's research on the functions related to the technical development investment strategies at the bakeries of Ukraine, as well as the results of expert support of investment, logistics and marketing projects of domestic enterprises [1, 2], a common problem for industrial enterprises in Ukraine is an inconsistent general development strategy of enterprise with its investment, production and functional strategies, which leads to disproportions between functional departments (Fig. 1) [1, 3]. As a result, there occurs duplication of responsibilities and performance works of employees, time for operations increases, the process of management at various levels gets complicated, the coordination of the enterprise as a system as a whole disturbs. Specifically, the problem appears during the development and implementation of functionally interrelated strategies with a strong degree of mutual influence if the delay in implementation of one of these strategies will reduce the effect of the implementation the others. Among such strategies, an innovation development strategy of a company can be identified. Problems of implementation lead to reduced effectiveness of the general development strategy and the deterioration of its functioning on the background of a rapidly changing external environment and the influence on it the negative external factors [4].

Literature review. The disclosure level of research on the functional connections between the different strategies of a company is growing, but the issues of the interaction of employees in different departments engaged in the development process and implementation of the development strategy and so-called "strategic triad": innovation, production and marketing strategies - remain elucidated. In recent years, among the groups of authors devoting their research studies to this subject, we can distinguish the following: S. Voytko, M. Kravchenko, studying

(C) Danyliuk V., Riepina I., Shafalyuk O., Kovylina M., Nitsenko V., 2020 the principles of management complexity [5], H. Shvindina, emphasizing the connections between the main elements of the strategy of innovation development of a company [6], L. Oliynyk, A. Kuznietsova, J. Gans, S. Stern, J. Wu, exploring the development strategy of an enterprise [7, 8], N. Chukhray, A. Stegnytskyi, V. Nitsenko, A. Mardani, I. Kuksa, and L. Sudarkina directing attention to the modeling of organizational process of interaction of innovation development management [9, 10], A. Mackelprang, E. Bernardes, G. Burke, C. Welter, Yi-Ch. Liao, and K.-H.Tsai dealing with the tasks of comprehensive improvement of the enterprise innovation strategy [11, 12], V. Coda, M. Minoja, M. Zollo, investigating the connections between different strategies of a company [13], N. Hakobyan, A. Khachatryan, N. Vardanyan, Y.Chortok, L. Starchenko, exploring the effectiveness of implementing the corporate social and environmental responsibility principles into the company's strategy [14], A. Zhulavskyi, D. Smolennikov, N. Kostyuchenko, investigating the connections between a company's readiness to implement social and environmental responsibility programs and choosing a perspective strategic alternative [15].

Actual and important for the scientific and practical elaboration are the problems of effective system application of innovative oriented interconnected strategies by enterprises, effective integration of proactive efforts of all business units and subsystems.

Purpose. The purpose of this research is to clearly define the contents and components of the technical development investment strategy of a company, to identify the key components of the company's strategic set, to compare these strategies and to find their intersection points that will help to identify the key elements of the mutual influence of one strategy on another and facilitate understanding of the functional intersection and functions of the departments' chiefs and effective use of vertical and horizontal coordination mechanisms. 


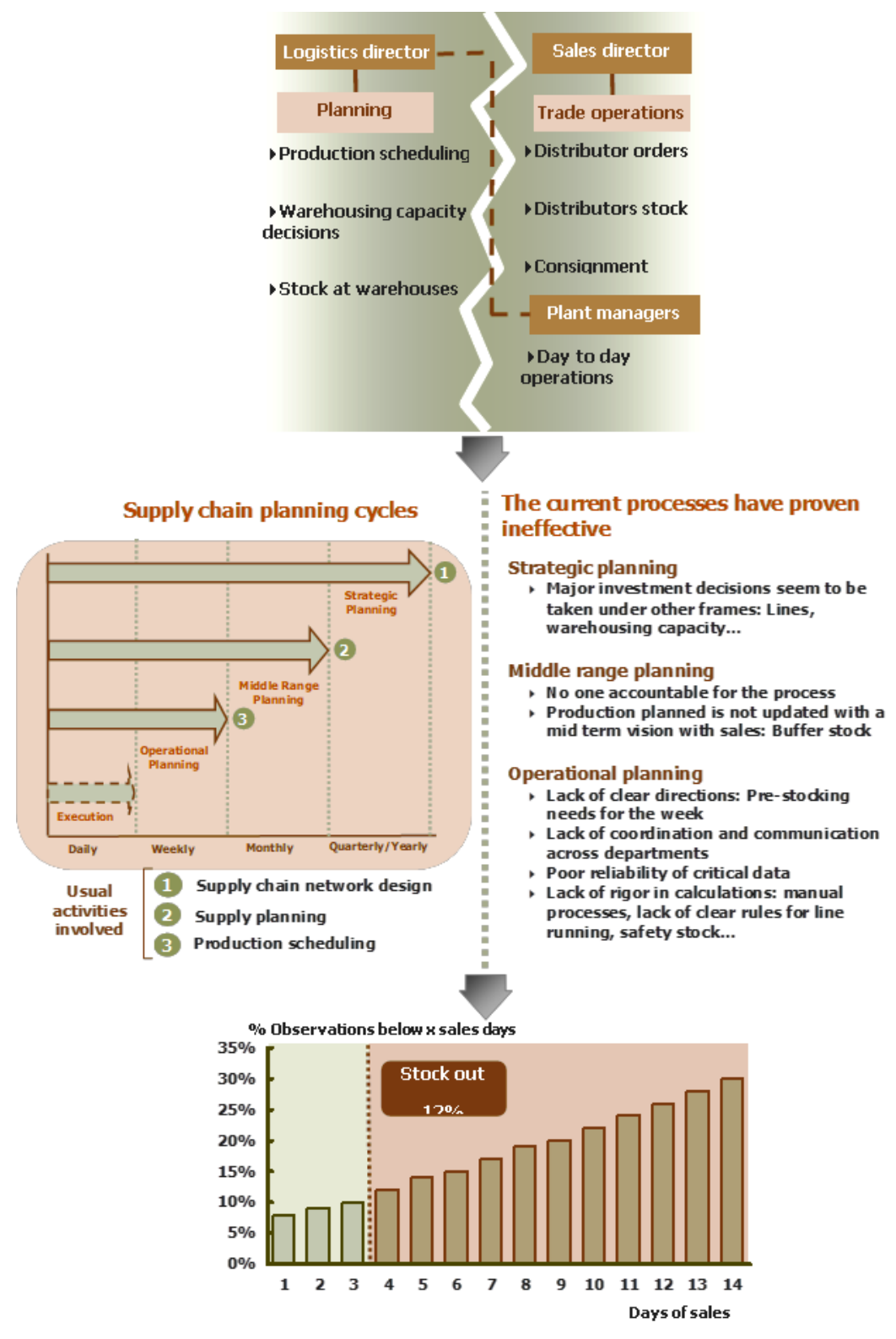

Fig. 1. Poor fulfillment of requirements due to poor coordination between departments $[1,3]$

Methods. In the research, general scientific methods of cognition were used, which made it possible to constructively systematize the approaches, concepts and factors of the effectiveness of a set of enterprise strategies. The procedures also included methods of analysis and synthesis in working out the problematic issues of integration of strategic management subsystems, as well as methods of systematic thinking in determining patterns of evolution, and the harmonization of interrelated strategies across different time horizons.

Results. Selection and use of some technical development form require the enterprise to develop a program of action to implement technical changes including support staff, resources, terms of competitive advantages of technical system [16]. The choice of such a set of actions regarding the technical development of the company and the principles of its implementation is carried out while forming its development strategy.

There is no unambiguous interpretation of this concept in the economic literature and reviews. The most general idea is that the technical development strategy involves set and reviewed variants of improving the technical level of the company; each of them has its own goals and ways of their achievement for the effective functioning of the enterprise and reaching the acceptable level of profitability. However, this defini- tion does not specify the type and characteristics of this strategy relatively to other strategies of the company. According to A. Nalyvaiko, the technical development strategy as a kind of resource-providing enterprise strategies cannot have objectively unambiguous methodical and conceptual approaches to its forming. This can be explained by complexity of the innovate development structure, the unevenness of this process both in time and in specific manifestations, and, most importantly, by different degree and areas as the impact of technical measures on the general strategy of the company, and also depending on it $[9,17]$.

Implementation of certain technical progress measures can have principally important or even revolutionary significance for the economic subjects [18]. In this case, such measures are the general strategy of the company (new high-efficiency technologies, progressive materials, and others). Thus, the technical development will have a sharp acceleration with intermittent pathway. Obviously, if the current and long-term planning of such measures takes place, then the methods of direct calculation are used widely both in terms of ensuring their implementation and in terms of the effect of these measures. A much larger share (their number) of technical measures has not such impact on the resulting parameters of com- 
pany's activity, but the impact of each of them can be measured both quantitatively and qualitatively [19]. It makes to a certain extent technically easier and possible the planning and implementation of these measures and mutual coordination of the technical development strategy with other chapters of the general strategic plan. An occasion should be stressed that if there is quantitative and qualitative measurability present, then such conditions of their implementation are effective enough as well as those of existence of the necessary funds for the implementation of relevant investment projects. The undeniable statement is that for the long-term and current management of this technical measures group, necessary basic elements exist and we can talk about their improvement.

Another group of technical measures (according to the quantitative composition, perhaps the most) can include those ones that have "flow-synergistic value" [20]. First, it concerns such measures that form the current, the tactical plans or such measures that are additional to the measures of the first two groups, or they are concerned in terms of the organizational and technical feasibility which is set in the current period. Second, quantitative and qualitative results of implementing this group of activities can be presented in long-term plans only in the total form, i.e. as a common task or expected total effect. But ambiguity of concrete semantic aspect of these activities during the forming of strategic plans leads to the necessity for the appropriate theoretical basis and methodical investigation to build an adequate strategic management system.

With the foregoing aspects, in the authors' opinion, the technical development strategy is a providing strategy of resource type that contributes to sustainable consolidation of the company in choosing their business direction by means of obtaining new characteristics of the system or supporting existing quantitative and qualitative ones.

In market economy, strategies of technical development and investment are defined at the level of the board of directors and (or) the head office of the company. The technical development strategy does not exist in isolation from the set of strategies of the company. As it was noted, it is a providing strategy and must be included in the general concept of the development strategy of the company. The connections between the strategies are as follows:

1. With a marketing strategy in the context of identifying the key areas of enterprise's market activity relatively to customers and competitors [12]. For its part the technical development strategy provides manufacturing of a new product which is demanded, and gradually reduces the cost of its production through, for example, technical re-equipment of production. Thus, the company aims to achieve the competitive advantages that are taken into account when the marketing strategy is formed. This strategy is considered as one of the leading functional strategies of the company. The importance of marketing strategy is explained by the fact that marketing provides information, strategic and operational ties with the enterprise's environment. As a result, the direct marketing subsystem operation is closely linked with other subsystems of the enterprise's management, including production and the process of technical development. Marketing experts provide information to the technical development experts concerning new features, with which a new product of a company must be endowed. It is possible through the system of reports regarding the new products, competitive advantages and so on. In turn, technical development experts together with specialists from production subsystem analyze what changes in the technical system must occur in order to realize the manufacturing of the product with new characteristics. The marketing strategy forming is based on forecasts of long-term prospects of the market development and the possibilities of a company, including technical capabilities.

2 . With the production strategy in forming of productbased strategies and during the process of its implementation, a number of administrative decisions regarding the purchase of a new production; modernization, reconstruction, technical re-equipment of existing production processes; improvement of the structure of the main, supporting and production processes. Also we can admit logistics strategy as a part of production strategy. The interaction of staff involved in logistics and technical development can occur in a matter of attracting new internal and external sources to satisfy the needs of material and technical resources and implement the progressive norms of resource spending.

According to E. Minaev and co-authors, the strategic decisions in production among other groups of decisions include technological decisions that are interpreted as a set of strategies that determine the dynamics of engineering and technology and form a technological profile of the company.

According to Z. Shershniova among other components that are reflected in the technical development strategy the meaningful content of production strategy determines:

1) the introduction of advanced technology and improvement of technical and organizational level of production;

2) cost savings by reducing the cost of raw materials, energy and so on;

3) modernization, technical re-equipment, reconstruction, acquisition of production capacity;

4) diversification and conversion of manufacturing processes.

With the foregoing aspects, one can conclude that the production strategy and technical development strategy of a company have a number of common points, which has a direct impact on the successful implementation of both strategies:

1) the degree of progressivity and used technologies at the enterprise needed to update their production strategy if it is changed;

2) the degree of availability of production needed to implement a new production strategy for spatial, technical, raw material, energy, information and human resources;

3 ) the degree of flexibility of technical system that is available for a company and its ability to absorb new products, new technological processes and methods of production and labor organization, etc.

This group of factors plays the major role among other endogenous factors, because of the fact that technical system existence is one of the key criteria for the enterprise selecting the version of its new production strategy and technical development strategy. The nature, structure, age and availability of machinery and applied technologies in some cases constitute effective starting conditions for the implementation of the advanced production strategy and technical development strategy; in other cases they impose substantial restrictions on implementing the selected variant of strategic actions.

Relatively to changes in the production strategy, T. Omelianenko notes that in situations of technocratic restructuring of production speaking about the transition to work in a fundamentally new technological solutions and using the last investigated technology, organizational factors, as opposed to technological ones limit not strictly the choice of a strategy, except the cases where the strategic focus is concentrated on the organizational and cultural context of restructuring. In such cases technical and technological base of the company is unchanged, while the organization of production activity is transferred to fundamentally different principles and success of such transfer is largely dependent on endogenous organizational factors [2].

3 . With the investment strategy in the context of establishing long-term investment objectives, selection of areas of technical development in conditions of ensuring a certain level of efficiency of implementing measures. Relevant experts of the enterprise seek for opportunities of the investment strategy implementation within existing resource potential. As technical development strategy is a strategy of resource type, it is also considered if the investment strategy was being formed, because it allows understanding how the company is investment- 
attractive in terms of technical capabilities. One of the tasks that the investment strategy solves is the operational management of investment activity through efficient management of investment projects and programs that can include the areas of technical development, in the case of projects of such area of development.

It would be correct to distinguish financial strategy. The importance of this strategy is that all activities of the enterprise appear through the system of financial indicators; the balancing of functional tasks and their subordination to the achievement of the main goals of the company take place $[4,16]$. On the one hand, finance is a source or starting point for the forming of other strategies, including the technical development strategy, because the financial resources are often the critical limit of the capacity and activities of the company. The financial strategy allows focusing on ways of technical solutions that do not conflict with the adopted general strategy. So it is a kind of "filter" of the technical development strategy and it eliminates impossible technical development activities envisaged by the strategy at present. On the other hand, the basis for the development of the financial strategy is the analysis of the factors of effective use of financial resources in the long-term prospect to achieve the objectives, including the technical goals of the enterprise. Therefore, the technical development experts should promptly draw up the technical development plans and the experts of the financial department will have the possibility to take them into account (or not) when forming the company's budgets.

The optimality and investment attractiveness of strategic decisions varies significantly for different time horizons. Technically, it is possible to quickly improve the demand fulfillment function of the exemplified enterprises by using the prestocking warehousing space of distributors $[1,2]$.

However, while maintaining the current policy in organizing the work of the logistics system, distributor stocks will critically grow over the next five years (Fig. 2). They will require additional discounts and compensation. This way, in the long run, expensive pre-storage will quickly fall outside the optimum range.

When pre-storage exceeds 85639 pallets per month, installing a new line becomes a more economical solution. Such investments in production reduce the time of order fulfillment and reduce the need for warehousing.

Situation modeling and detailed calculations show the need to optimize strategic management systems, confirm the effectiveness of investments in technical development (Fig. 3).
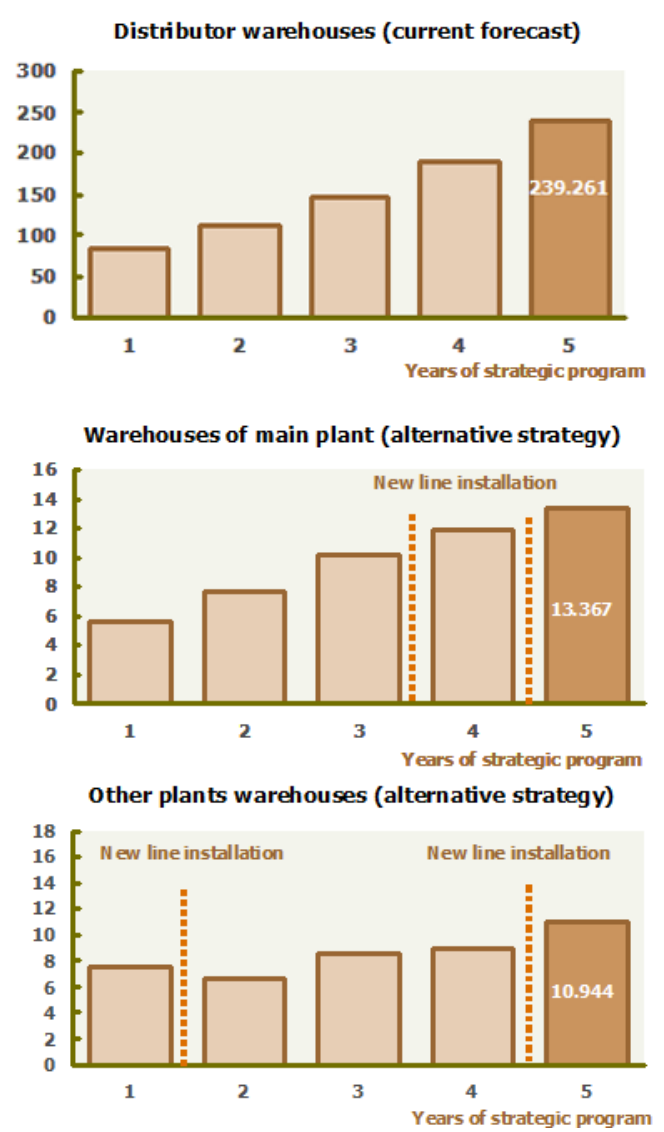

Fig. 2. Strategy variants of depot network development $[1,3]$

4. With the HR strategy in the context of recruitment, training, retraining and inducing the employees appropriating the needs of the technical development strategy. The technical services' experts related indirectly (through a common HR subsystem) to the forming of this strategy as it relates to the rationalization and forming the programs of measures to ensure the normal process of reproduction of labor at the enterprise and maintaining a healthy microclimate in the team. The implementation of such measures improves the employees' productivity growth and therefore affects the course of the production process and technical development. Also the implementation of the organization strategy as a part of the HR strategy may involve changing the organizational structure of
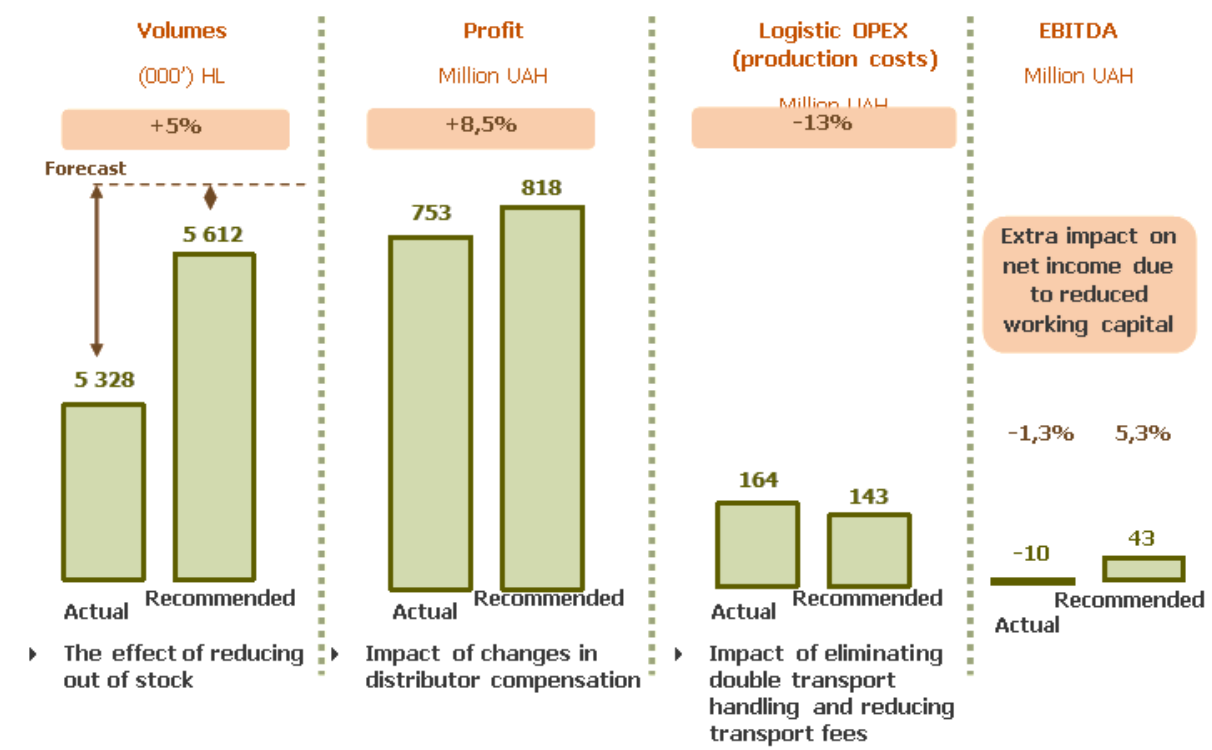

Fig. 3. Financial performance of a new model of industrial and commercial activities in a long-term strategy [1, 3] 
units engaged in technical development, but it is not affected directly by the planning of technical development.

5. In the context of the innovation strategy to focus on finding the most perspective areas of technical development of the enterprise, manufacturing of new products and services using research, advanced technologies that ensure efficient use of resources. They also provide determining the future all-type-recourse needs of the enterprise, coordination and distribution of enterprise resources that are needed to implement the technical development strategy. The experts involved in the forming and implementation of this strategy are to interact with the experts involved in the forming of the technical development strategy, as the latter affects directly the implementation of the innovation strategy through the product life cycle, market position of the company and its technical policy.

The interaction of staff (stakeholders) [19] involved in the implementation of the production strategy and technical development strategy is as follows:

1) production planning and control. The participation of production units in the process of study and development of the general development strategy is passive, as production plans relate to tactical decisions rather than to strategic ones. However, the management of production units takes part in the development of the next principle decisions;

2) identification of opportunities to use existing equipment and the need for its modernization. The solution of this task relates directly to units (specialists) engaged in technical development as the issue of increasing the effective use of assets is one of the key areas of technical development;

3) trending relationships with staff in the issue of raising the skills level and examination of business units for the production process. As far as it concerns training the staff in transition to a higher technical level, it is partly a question concerning the technical experts because technical development planning should take place in conjunction with the planning of training of production personnel. To do this, managers of production units have to conduct the examination in departments that are responsible for technical development (in case if it is not a production unit) to coordinate the process of technical changes and appropriate training of workers;

4) increase in productivity. If productivity is associated with the use of equipment with the best technical specifications and not, for example, accelerated execution of manual operations, it also requires coordination with technical development experts.

The issue of increasing the productivity is taken into account in the forming of technical development strategy. This area of the enterprise may involve the collaboration of technical development specialists and production units in:

- the analysis of productivity factors and identification of "bottlenecks";

- productivity increase through the improvement of system and structure of production management;

- forming of a program of measures to improve productivity. The objectives of the production strategy that should be consistent with the objectives of technical development strategy are: optimal capacity utilization, lower production costs, quality of production, conformity of technical and production complexity level of enterprise.

According to the author's research on functions relating to the strategies that are connected with the technical development strategy which took place at 9 bakery enterprises of Ukraine, the following can be proved:

1. Within the production strategy, the decisions regarding the purchase or organization of new production, modernization, reconstruction, technical re-equipment of productive capacities are made, but the structure of the main, auxiliary, service industries and the proportion between them are not improving.
2. Within the investment strategy, the funds for investment activities of technical development and implementation of a set of the most effective ways to achieve them are not involved.

3 . Within the innovation strategy, the search of the most perspective areas of enterprises' technical development, production of new products and services using research studies, advanced technologies that ensure efficient use of resources is executed, but within innovation strategy, technical strategies are not forming.

4. Within the marketing strategy, the main directions of enterprises in the market relating to the study of demand for new products are defining; however, the analysis of the bakery market demand trends for the products of the industry and, consequently, the amount of necessary equipment is hardly executed, and also the demand for sampled enterprises products of importing countries is not investigating, the level of sales of such equipment is not forecast.

5. Within the HR strategy, the work of training, retraining and incentives for workers that accords the needs of production in the conditions of approving the technical and technological knowledge, abilities, skills, such as work with new modern equipment is not carried out.

Conclusions. Having critically analyzed the different views on the concept of technical development strategy and systematized the common substantive its characteristics, we determined that the technical development strategy is a providing strategy that contributes to sustainable consolidation of the company in their business direction chosen by means of obtaining the new or supporting the existing competitive advantages of the enterprise's technical system and it is aimed at achieving the objectives of the company by retaining or improving the existing technical level of the company.

According to the research, the connection of technical development strategy was shown with general, production and functional strategies that are usually included in the strategic set of a company; also the need was emphasized for an integrated approach to shaping the technical development strategy as a means of achieving the objectives of the general development strategy.

Special attention in the functional division of responsibilities between the mid-level managers of the production company should be paid to "strategic triad": the production strategy, marketing strategy, and innovation strategy of the company and their common elements. Viewing the place of technical development investment strategy in the strategic set of a company directly, it was shown that it can be crucial in terms of delivering the general development strategy in high-tech companies and has both distinct and derived elements in terms of implementation of production and innovation strategies. These strategies have one vector of development and implementation and rely on one another.

As a synthesis result of the data on the system of enterprise's strategies, their characteristics and critical points of crossing, it was distinguished the particularities of strategic management, which are as follows:

1. As the technical development investment strategy is a providing strategy and it subordinates to the achievement of the main goal of a company, it cannot be articulated until the general strategy of the company isdetermined.

2. The ultimate goal of the company should be clearly defined to formulate the principles and directions of investment.

3. The development management (as well as the forming and implementation of the development strategy) is engaged in multiple departments (services) that provide their cooperation, which should be clearly defined and regulated.

The further area of researching the problem of the forming and implementation of the technical development investment strategy of the enterprise and functional connections between employees of different divisions is a deep analysis and separation of general and special functions of development of the enterprise that is oriented on the strategic approach to the management process. 
References.

1. Building a demand-driven logistics operation in Ukraine (n.d.). Retrieved from: https://www.globalpraxis.com/projects.

2. Shafalyuk, A. K. (2017). Marketing-oriented clusters in the development of logistics systems of industrial enterprises. Ekonomika and entrepreneurship, 39, 326-336.

3. Ivanova, M. (2017). Theoretical aspects of the system decomposition of the logistics system elements. Naukovyi Visnyk Natsionalnoho Hirnychoho Universytetu, (4), 132-139.

4. García-Cabrera, A., García-Soto, M., \& Olivares-Mesa, A. (2019). Entrepreneurs' Resources, Technology Strategy, and New Technology-Based Firms' Performance. Journal of Small Business Management, 4, 1506-1530. https://doi.org/10.1111/ jsbm.12411.

5. Voytko, S. V., \& Kravchenko, M. O. (2017). The formation mechanism of economic sustainability of the machine-building enterprises (neo-system approach). Marketing and Management of Innovations, 2, 211-221. https://doi.org/10.21272/ mmi.2017.2-20.

6. Shvindina, H. O. (2017). Innovations of strategic management development: from competition to coopetition. Marketing and Management of Innovations, 1, 180-192. https://doi. org/10.21272/mmi.2017.1-16.

7. Oliynyk, L. V., \& Kuznietsova, A. P. (2018). Methodological principles of enterprise development strategy formation. Economics and organization of management, 3, 118-126.

8. Gans, J., Stern, S., \& Wu, J. (2019). Foundations of entrepreneurial strategy. Strategic Management Journal, 5, 736-756. https://doi.org/10.1002/smj.3010.

9. Chukhray, N. I., \& Stegnytskyi, A. V. (2015). Integrated assessment of scientific and technical development at early stages of innovative process. Marketing and Management of Innovations, 1, 11-23.

10. Nitsenko, V., Mardani, A., Kuksa, I., \& Sudarkina, L. (2018). Additional opportunities of systematization the marketing research for resource conservation practice. Management Theory and Studies for Rural Business and Infrastructure Development, 40(3), 361-368. https://doi.org/10.14254/18005845/2018.14-3.18.

11. Mackelprang, A., Bernardes, E., Burke, G., \& Welter, C. (2018). Supplier Innovation Strategy and Performance: A Matter of Supply Chain Market Positioning. Decision Sciences Journal, 4, 660-689. https://doi.org/10.1111/deci.12283. 12. Liao, Yi-Ch., \& Tsai, K.-H. (2019). Innovation intensity, creativity enhancement, and eco-innovation strategy: The roles of customer demand and environmental regulation. Business Strategy and the Environment, 2, 316-326. https://doi. org/10.1002/bse.2232.

13. Zollo, M., Minoja, M., \& Coda, V. (2018). Toward an integrated theory of strategy. Strategic Management Journal, 6, 1753-1778. https://doi.org/10.1002/smj.2712.

14. Hakobyan, N., Khachatryan, A., Vardanyan, N., Chortok, Y., \& Starchenko, L. (2019). The Implementation of Corporate Social and Environmental Responsibility Practices into Competitive Strategy of the Company. Marketing and Management of Innovations, 2, 42-51. https://doi.org/10.21272/ mmi.2019.2-04.

15. Zhulavskyi, A. Yu., Smolennikov, D. O., \& Kostyuchenko, N. M. (2017). Social and environmental responsibility strategies of business. Naukovyi Visnyk Natsionalnoho Hirnychoho Universytetu, (3), 134-139.

16. Jia, N. (2017). Corporate Innovation Strategy, Analyst Forecasting Activities and the Economic Consequences. Journal of Business Finance \& Accounting, 5-6, 812-853. https:// doi.org/10.1111/jbfa.12242.

17. Klingebiel, R., \& Joseph, J. (2016). Entry timing and innovation strategy in feature phones. Strategic Management Journal, 6, 1002-1020. https://doi.org/10.1002/smj.2385.

18. Baharun, R., Jing Mi, T., Streimikiene, D., Mardani, A., Shakeel, J., \& Nitsenko, V. (2019). Innovation in healthcare performance among private brand's healthcare services in small and medium-sized enterprises (SMEs). Acta Polytechnica Hungarica, 16(5), 151-172. https://doi.org/10.12700/ APH.16.5.2019.5.9.

19. Strojny, J., \& Jedrusik, A. (2018). Stakeholder Analysis during a Reorganization Project in Local Government Institutions Key Methodological Aspects. Marketing and Management of Innovations, 4, 372-381. https://doi.org/10.21272/mmi.2018.4-32. 20. Xionglin, Zh., Jingjun, P., \& Caiyun, Zh. (2016). Third party logistics provider service performance evaluation based on triangular fuzzy topsis. Naukovyi Visnyk Natsionalnoho Hirnychoho Universytetu, (3), 140-145.

\section{Функціональні та інвестиційні стратегії технічного розвитку підприємств}

\author{
В. О. Данилюк ${ }^{1}$, I. М. Репіна ${ }^{1}$, О. К. Шафалюк ${ }^{1}$, \\ М. О. Ковиліна ${ }^{2}$, В. С. Ніценко
}

1 - Київський національний економічний університет імені Вадима Гетьмана, м. Київ, Україна

2 - Національний університет «Одеська морська академія», м. Одеса, Україна

3 - Міжрегіональна академія управління персоналом, м. Київ, Україна, e-mail: vitaliinitsenko@gmail.com

Мета. Ідентифікація зв'язків між основними елементами стратегічного набору компанії, проблем і можливостей їх ефективної реалізації взаємодіючими підрозділами підприємств.

Методика. У дослідженнях елементів і підсистем, підходів і концепцій стратегічного управління підприємствами, а також можливостей їх ефективної інтеграції, використані методи системного аналізу й загальнонаукові, що забезпечило результативність узагальнень і конструктивність висновків.

Результати. У дослідженні проаналізовані поширені проблеми дисбалансу між загальною стратегією розвитку підприємства та його інвестиційними, виробничими й функціональними стратегіями, що призводить до зниження результативності управління та ефективності бізнесу. Стаття містить різні погляди стосовно концепції розробки стратегії технічного розвитку та ії̈ взаємозв'язку з інвестиційними, виробничими та функціональними стратегіями, що зазвичай включаються до стратегічного набору компанії. У результаті дослідження визначені можливості комплексної оптимізації стратегічної тріади в досягненні цілей загальної стратегії розвитку підприємства.

Наукова новизна. У результаті узагальнення даних щодо системи стратегій діяльності підприємства були визначені критичні точки їх перетину, а також виявлені особливості ефективного стратегічного управління.

Практична значимість. На основі систематизації й розвитку теоретичних основ, а також аналізу результативності стратегічного управління діяльністю українських підприємств для них визначені шляхи нейтралізації проблем у формуванні та впровадженні функціонально взаємопов'язаних інноваційно-орієнтованих стратегій, підвищення ефективності інвестицій, що гармонізовані за різними стратегічними горизонтами.

Ключові слова: інвестиції, інновації, технічний розвиток, стратегія, управління

\section{Функциональные и инвестиционные стратегии технического развития предприятий}

\author{
В. А. Данилюк ${ }^{1}$, И. Н. Репина ${ }^{1}$, А. К. Шафалюк ${ }^{1}$, \\ М.А. Ковылина ${ }^{2}$, В. С. Ниценко
}


1 - Киевский национальный экономический университет имени Вадима Гетьмана, г. Киев, Украина

2 - Национальный университет «Одесская морская академия», г. Одесса, Украина

3 - Межрегиональная академия управления персоналом, г. Киев, Украина, e-mail: vitaliinitsenko@gmail.com

Цель. Идентификация связей между основными элементами стратегического набора компании, проблем и возможностей их эффективной реализации взаимодействующими подразделениями предприятий.

Методика. В исследованиях элементов и подсистем, подходов и концепций стратегического управления предприятиями, а также возможностей их эффективной интеграции, использованы методы системного анализа и общенаучные, что обеспечило результативность обобщений и конструктивность выводов.

Результаты. В исследовании проанализированы широко распространенные проблемы дисбаланса между общей стратегией развития предприятия и его инвестиционной, производственной и функциональной стратегиями, что приводит к снижению эффективности управления и эффективности бизнеса. Статья содержит различные взгляды относительно концепции разработки стратегии техниче- ского развития и ее взаимосвязь с инвестиционными, производственными и функциональными стратегиями, которые обычно входят в стратегический комплекс компании. В результате исследования определены возможности комплексной оптимизации стратегической триады в достижении целей общей стратегии развития предприятия.

Научная новизна. В результате обобщения данных о системе стратегий предприятия были изучены критические точки их пересечения, а также определены особенности эффективного стратегического управления.

Практическая значимость. На основе систематизации и развития теоретических основ, а также анализа результативности стратегического управления деятельностью украинских предприятий для них определены пути нейтрализации проблем в формировании и внедрении функционально взаимосвязанных инновационно-ориентированных стратегий, повышения эффективности инвестиций, которые гармонизированы между разными стратегическими горизонтами.

Ключевые слова: инвестиции, инновации, техническое развитие, стратегия, управление

Recommended for publication by I. Gontareva, Doctor of Economic Sciences. The manuscript was submitted 14.09.19. 